\title{
AN EXTENSION SYSTEM OF SEQUENTIAL DIFFERENTIAL EQUATIONS OF ARBITRARY ORDER
}

\author{
HAMMOU BENMEHIDI and ZOUBIR DAHMANI
}

\begin{abstract}
We are concerned with an extension of a coupled sequential differential system of fractional type. Using the Banach contraction principle, we establish new results for the existence and uniqueness of solutions. Then, we prove another existence result via Schaefer's fixed point theorem. At the end, we illustrate one main result by an example.
\end{abstract}

MSC 2010. 34A08, 34B10.

Key words. Caputo derivative, Hadamard derivative, fixed point, existence, sequential differential equation.

\section{REFERENCES}

[1] S. Asawasamrit, S. Ntouyas, J. Tariboon and W. Nithiarayaphaks, Coupled systems of sequential caputo and hadamard fractional differential equations with coupled separated boundary conditions, Symmetry, 10 (2018), 1-17.

[2] B. Ahmad, A. Alsaedi, S.K. Ntouyas and J. Tariboon, Hadamard-type fractional differential equations, inclusions and inequalities, Springer, Cham, 2017.

[3] R.L. Bagley and P.J. Torvik, A theoritical basis for the application of fractional calculus in viscoelasticity, Journal of Rheology, 27 (1983), 201-210.

[4] M. Benchohra and J.E. Lazreg, Existence and Ulam stability for non-linear implicit fractional differential equations with Hadamard derivative, Stud. Univ. Babeş-Bolyai Math., 62 (2017), 27-38.

[5] K. Diethelm and N.J. Ford, Analysis of fractional differential equations, J. Math. Anal. Appl., 265 (2002), 229-248.

[6] A. Granas and J. Dugundji, Fixed point theory, Springer-Verlag, New York, 2005.

[7] A.A. Kilbas, Hadamard-type fractional calculus, J. Korean Math. Soc., 38 (2001), 11911204.

[8] A.A. Kilbas, H.M. Srivastava and J.J. Trujillo, Theory and Applications of Fractional Differential Equations, North-Holland Mathematics Studies, Vol. 204, Elsevier, Amsterdam, 2006.

[9] K.S. Miller and B. Ross, An introduction to the fractional calculus and fractional differential equations, Wiley and Sons, New York, 1993.

[10] H. Rudolf, Applications of Fractional Calculus in Physics, World Scientific, Singapore, 2000.

The present paper is supported by DGRSDT Direction Generale de Recherche Scientifique et du Developpement Technologique, Algeria. The authors thank the referee for his helpful comments and suggestions.

DOI: $10.24193 /$ mathcluj.2021.2.04 
[11] B. Ross, Fractional Calculus and its Applications, Springer-Verlag, Berlin, 1975.

[12] J. Sabatier, O.P. Agrawal and J.A. Machado, Advances in fractional calculus: theoretical developments and applications in physics and engineering, Springer, Dordrecht, 2007.

[13] S.G. Samko, A.A. Kilbas and O.I. Marichev, Fractional integrals and derivatives, Gordon and Breach Science Publishers, Yverdon, 1993.

[14] J. Tariboon, A. Cuntavepanit, S.K. Ntouyas and W. Nithiarayaphaks, Separated boundary value problems of sequential Caputo and Hadamard fractional differential equations, J. Funct. Spaces, 2018, Article 6974046, 1-8.

[15] P. Thiramanus, S.K. Ntouyas and J. Tariboon, Positive solutions for Hadamard fractional differential equations on infinite domain, Adv. Difference Equ., 2016, Article 83, $1-18$.

Received December 09, 2019

Accepted May 28, 2020
University of Tiaret

Department of Nature and Life science

Algeria

University of Mostaganem

Faculty of SEI

Laboratory of Pure and Applied Maths

Algeria

E-mail: benmehidi-h@outlook.com

University of Mostaganem

Faculty of SEI

Laboratory of Pure and Applied Maths

Algeria

E-mail: zzdahmani@yahoo.fr 